\title{
IMPRENSA E DITADURA: os valores-notícia nos casos de religiosos acusados de praticar atividades subversivas
}

\author{
THE PRESS AND DICTATORSHIP: the news value in cases of \\ religious figures accused of practicing subversive activities
}

\author{
Eliane Muniz LACERDA ${ }^{1}$ \\ Robson DIAS ${ }^{2}$ \\ Victor Márcio Laus Reis GOMES 3 \\ Universidade Católica de Brasília | Brasil
}

\begin{abstract}
Resumo
Durante a ditadura militar no Brasil, a Igreja católica desempenhou importante papel na defesa dos direitos humanos, sobretudo a partir do momento em que religiosos foram acusados pelo regime de praticar atividades subversivas. Este estudo tem como objeto de pesquisa os cinco casos de religiosos perseguidos pela ditadura que tiveram maior repercussão nos jornais impressos de circulação nacional. O objetivo é analisar os valores-notícia das 53 matérias publicadas entre 1968 e 1977, que fizeram com que esses acontecimentos ganhassem as páginas noticiosas. O estudo empírico permitiu identificar e destacar quatro critérios: imprevisibilidade, personificação, referência a nações de elite e amplitude.

Palavras-chave

CNBB; imprensa; religiosos; valores-notícia; regime militar.

\section{Abstract}

During the Brazilian military dictatorship, the Catholic Church played an important role in defence of human rights, especially when priests were accused by the regime of practicing subversive activities. The objective of this study is to examine five cases of religious figures that were persecuted by the dictatorship, which wielded strong repercussions within the printed nation-wide news outlets. The objective is to analyze the news-values of the 53 articles published between 1968 and 1977, which made these events reach the headlines. The empirical study made it possible to identify and highlight four criteria: unpredictability, personification, elite-nation references and amplitude.

Keywords

CNBB; media; clergy; news-value; military regime.
\end{abstract}

\section{RECEBIDO EM 01 DE ABRIL DE 2020}

ACEITO EM 27 DE JULHO DE 2020

\footnotetext{
1 JORNALISTA. Doutoranda e mestre em Comunicação pela Universidade de Brasília. Professora e pesquisadora do curso de Comunicação Social da Universidade Católica de Brasília (UCB). Contato: eliane.muniz@gmail.com.

2 JORNALISTA. Mestre e doutor em Comunicação. Pesquisador no Programa de Pós-Graduação em Comunicação, linha Processos Comunicacionais nas Organizações (PPGCOM/UCB). Contato: robson.dias@ucb.br.

${ }^{3}$ Publicitário, mestre em Administração e doutor em Comunicação. Pesquisador no Programa de PósGraduação em Comunicação, linha Processos Comunicacionais nas Organizações (PPGCOM/UCB). Contato: victorgomes.ucb@gmail.com.
} 


\section{Introdução}

o observar a história da Igreja católica no Brasil, percebe-se que a
luta travada durante a ditadura não foi o primeiro conflito entre
Igreja e Estado. A instituição religiosa já detivera muito mais poder do que na época do Regime Militar. No Império, ela controlava a emissão de certidões de nascimento, casamento, óbitos. Os cemitérios também estavam sob sua responsabilidade e neles só podiam ser enterrados aqueles que professassem a fé católica. Tinham direito à herança apenas os filhos de pais casados na Igreja. A instituição cumpria, portanto, funções que eram de responsabilidade do Estado. Essa situação tornou-se grande preocupação para este último, desde o fim do século XIX, pois cada vez mais chegavam ao país pessoas de várias etnias e de diferentes crenças. Por outro lado, embora exercesse funções públicas, a Igreja era também controlada pelos que governavam. Ela não conseguia se expandir, pois era o Estado que determinava a criação dos bispados, nomeava os bispos, os professores de seminário, determinava o rol dos livros que se podia ensinar no seminário (DINES; FERNANDES Jr.; SALOMÃO, 2000).

Em 7 de janeiro de 1890, aconteceu oficialmente a separação entre Igreja e Estado no Brasil ${ }^{4}$ (BRUNEAU, 1974, p. 65). Este passou, portanto, a assumir as funções públicas até então sob a responsabilidade da Igreja católica, com alguns efeitos. Entre eles: a privação dos direitos políticos aos membros das ordens religiosas, congregações e comunidades; o reconhecimento oficial do casamento civil; a secularização e municipalização dos cemitérios; a exclusão do ensino religioso do currículo escolar.

Com o rompimento, a Igreja pôde se expandir pelo Brasil. No período do Império só havia doze bispados. Em 1930, este número passou para 130

\footnotetext{
${ }^{4} \mathrm{O}$ projeto de separação Igreja-Estado foi apresentado ao Conselho de Ministros por Rui Barbosa, e instituído a 7 de janeiro de 1890, por decreto assinado por Deodoro da Fonseca. A partir daí ficou estabelecida a plena liberdade de culto e a proibição às autoridades federais ou estaduais de intervirem em matéria religiosa.

João Pessoa - Brasil | ANO 7 VOL.7 N.2 | JUL./DEZ. 2020 | p. 180 a 202 


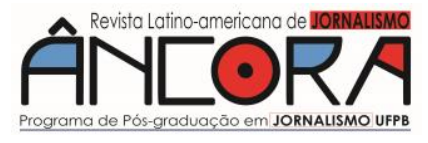

\section{Eliane LACERDA - Robson DIAS - Victor GOMES}

(DINES; FERNANDES Jr.; SALOMÃO, 2000). Com a separação, a Igreja "estava livre para exercer sua missão com maior autenticidade e testemunho evangélico mais transparente" (BARROS, 2003, p.153).

No período que se seguiu ao fim do Império, a Igreja foi reconquistando seu espaço social. Desde a separação, carregou consigo a preocupação com a questão da família, principalmente no que se referia ao divórcio e ao aborto. Lutou pelo direito de existirem escolas católicas e de o ensino religioso ser inserido no currículo das escolas públicas. Em suas articulações políticas, houve duas grandes iniciativas: a campanha pelo voto feminino, pois os religiosos consideravam que as mulheres poderiam votar no programa da Igreja sobre a questão da família e da escola; e a campanha de alistamento eleitoral, para que as pessoas obtivessem o título de eleitor ${ }^{5}$.

A separação entre Igreja e Estado, no final do século XIX, trouxe, portanto, vantagens e desvantagens para ambas as partes. Foi uma separação pacífica, se comparada à ocorrida, na época, em outros países. O Estado e a Igreja tinham interesses e procuraram manter boas relações.

Um novo conflito entre essas duas instituições voltou a ocorrer durante o regime militar no Brasil, sobretudo na década de 1970, quando a Igreja católica se viu comprometida diante da acusação de que seus religiosos estavam envolvidos com atividades subversivas. Somente de 1968 a 1978, 122 religiosos e 273 leigos foram presos e nove padres foram expulsos do país. Um bispo foi sequestrado e quatro padres morreram devido às consequências da ditadura (SOARES, 1988, p.270).

Religiosos e leigos foram tachados de subversivos e perseguidos pelo fato de o regime militar considerá-los uma ameaça comunista para a sociedade brasileira. $\mathrm{O}$ envolvimento de padres com índios, camponeses, operários e estudantes era razão suficiente para provocar prisão, tortura, expulsão do país

\footnotetext{
${ }^{5}$ As próprias paróquias eram os locais onde ocorriam os alistamentos.
} 
e até assassinato. Se o religioso fosse estrangeiro, a situação agravava-se mais, pois a Segurança Nacional não fazia distinção entre política interna e externa.

Alguns casos de religiosos acusados de praticar atividades subversivas foram silenciados pelo regime. Outros ganharam visibilidade na imprensa, conforme sua gravidade e o período em que eles ocorreram. De 1968 a 1977, com base na análise do arquivo jornalístico ${ }^{6}$ da Conferência Nacional dos Bispos do Brasil - CNBB, - foi constatado que a imprensa brasileira registrou 18 casos de religiosos acusados de praticar atividades subversivas, que se tornaram públicos, sobretudo porque continham em si valores-notícia capazes de fazer com que um acontecimento ganhasse as páginas jornalísticas. Outro fator que contribuiu para que essas ocorrências tivessem visibilidade foi a atuação da cúpula da Igreja, representada pela CNBB. A instituição religiosa teve importante papel como promotora de notícia, tanto na defesa dos religiosos como na luta pelo respeito aos direitos humanos. Tornou-se, além disso, importante fonte de informação em um momento em que as fontes, inclusive as oficiais, eram mais silêncio do que voz.

\section{Atuação da CNBB durante a ditadura militar}

Nos primeiros meses de instalação do regime militar no Brasil em 1964, a reação da Igreja foi de neutralidade, pois ela já se encontrava profundamente dividida. Alguns bispos, padres e lideranças viam no comunismo ateu o pior inimigo da fé. O Governo Militar, para eles, afastava o perigo comunista. Ao mesmo tempo, outros prelados combatiam a prática capitalista, à qual atribuíam o crescimento da divisão de classes e da miséria, defendendo um regime socialista.

\footnotetext{
${ }^{6} \mathrm{O}$ arquivo é parte do Centro de Documentação e Informação da CNBB. Está localizado na sede da entidade, em Brasília. Uma análise prévia permitiu contabilizar mais de três mil matérias relacionadas à atuação da Igreja católica durante a ditadura no Brasil.
}

João Pessoa - Brasil | ANO 7 VOL.7 N.2 | JUL./DEZ. 2020 | p. 180 a 202 


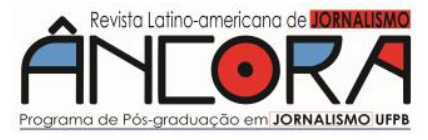

\section{Eliane LACERDA - Robson DIAS - Victor GOMES}

Para Serbin (2001, p.104), "até o início dos anos 1970, a maioria dos bispos mantinha uma cautelosa, porém esperançosa atitude em relação ao regime". Eles permaneceram em silêncio, enquanto alguns católicos sofriam as consequências da ditadura. Nos primeiros anos de regime, prevaleceu a posição da maioria dos bispos ligados à elite, que tinha preocupações doutrinárias e dogmáticas, como o matrimônio e o aborto, e que considerava o comunismo como o maior inimigo. Eis aí a principal razão para a Igreja apoiar o regime militar.

Muitos bispos só perceberam que os alegados objetivos da ditadura, de restabelecer a democracia no país e de combater a infiltração comunista, estavam ferindo os direitos humanos quando pessoas começaram a ser cassadas, aposentadas e exiladas. A Igreja só notou que:

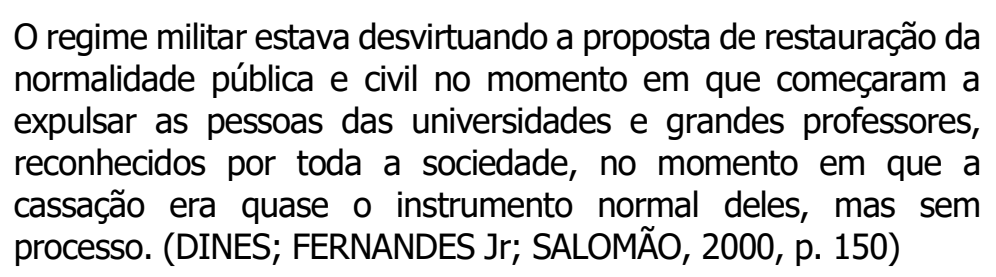

Logo, a CNBB, como órgão oficial da Igreja no Brasil, assumiu publicamente causas ligadas à justiça social e aos direitos humanos. Passou, portanto, a levantar a voz em favor dos segmentos politicamente perseguidos.

\section{A igreja perseguida}

No decorrer da ditadura, a alta hierarquia da Igreja foi constantemente acusada de não ter controle sobre sua base formada por padres, freiras e leigos. Muitos religiosos foram acusados de praticar atividades subversivas. Não era preciso estar ligado a movimentos guerrilheiros, bastava um sermão, uma homilia, para serem detidos, presos e torturados, issto porque os militares desconfiavam que parte da Igreja estivesse envolvida com comunistas. Para os militares, os religiosos não deviam se envolver com questões sociais. 0 engajamento de um padre ou de uma freira na luta pela terra, na luta dos 
operários ou da juventude significava grande ameaça para o regime. As ações sociais praticadas pelos religiosos eram entendidas pelos militares como infiltração comunista. Nem os bispos escaparam das acusações do regime. Os mais perseguidos foram o arcebispo de Olinda e Recife, dom Helder Câmara, e o bispo de São Félix do Araguaia, dom Pedro Casaldáliga.

Dom Helder Câmara foi uma figura popular na Igreja, tanto em âmbito nacional como internacional. Foi fundador da CNBB e esteve profundamente engajado em atividades pastorais. Dom Helder foi assistente geral da Ação Católica Brasileira, que posteriromente passou a ser chamada Ação Católica Especializada e da qual faziam parte a Juventude Agrária Católica - JAC, Juventude Estudantil Católica - JEC, Juventude Independente Católica - JIC, Juventude Operária Católica - JOC, Juventude Universitária Católica - JUC, Ação Católica Operária e a Ação Católica Rural. Muitos desses movimentos católicos encontravam-se alinhados aos demais movimentos sociais. A JUC envolveu-se, por exemplo, com a União Nacional de Estudantes - UNE, chegando a ter, em 1961, um de seus membros eleito presidente do movimento estudantil. A JOC esteve ligada às manifestações operárias e a JAC, aos desafios do campo. Internacionalmente, dom Helder tornou-se célebre por suas denúncias sobre as atrocidades da ditadura no Brasil.

Já dom Pedro Casaldáliga, falecido recentemente, em 8 de agosto de 2020, era de nacionalidade espanhola e ficou conhecido por seu envolvimento com a luta pela terra. Por ser estrangeiro, foi ameaçado de expulsão por muitos anos. Ele foi um dos fundadores do Conselho Indigenista Missionário, organismo ligadado à CNBB e criado em 1972.

Dom Pedro foi alvo de inúmeras ameaças de morte. A mais grave, em 12 de outubro de 1976, ocorreu em Ribeirão Cascalheira (Mato Grosso). Ao ser informado que duas mulheres estavam sendo torturadas na delegacia local, dirigiu-se até lá acompanhado do padre jesuíta João Bosco Penido Burnier. Após forte discussão com os policiais, o padre Burnier ameaçou denunciá-los às autoridades, 


\section{Eliane LACERDA - Robson DIAS - Victor GOMES}

sendo então agredido e, em seguida, alvejado com um tiro na nuca. Naquele lugar foi erguida uma igreja? .

Se os bispos foram alvos do regime, muito mais os padres. A maioria das acusações ocorria por causa do envolvimento de sacerdotes com questões sociais. Nem todos os casos foram divulgados pela imprensa. Alguns, porém, pela dimensão dos acontecimentos, tiveram repercussão nacional e até internacional. As acusações contra os religiosos estrangeiros sempre tiveram mais visibilidade do que aquelas contra religiosos brasileiros.

\section{Procedimentos metodológicos}

O tema deste trabalho foi delimitado aos casos de religiosos que sofreram repressões (prisão, tortura, ameaças de expulsão) durante o regime militar, por se tratar de um assunto que atingiu diretamente a Igreja, e dela exigiu manifestação pública a respeito. Foram selecionados cinco casos significativos, dos dezoito que constam no arquivo jornalístico da CNBB, sendo:

1) dos religiosos franceses da Congregação dos Agostinianos da Assunção, em Belo Horizonte, padres Michel Le-Ven, Xavier Berthon, Hervé Crouguennac, que foram presos em novembro de 1968 por seu envolvimento com os operários daquela região;

2) do padre suíço Romain Zufferrey, preso durante o governo de Geisel, em julho de 1977;

3) de dom Pedro Casaldáliga, ameaçado de expulsão do país em 1977;

4) do padre François Jentel, preso e expulso do país em 1975. Ele trabalhava com a questão da terra, na Prelazia de São Félix do Araguaia, junto a dom Pedro Casaldáliga;

5) dos religiosos dominicanos presos e torturados em dezembro de 1969, por seu envolvimento com os estudantes, especialmente com a União Nacional dos Estudantes e a Juventude Universitária Católica,

\footnotetext{
${ }^{7}$ Morre bispo emérito da Prelazia de São Félix do Araguaia (MT), dom Pedro Casaldáliga. CNBB. Disponível em: https://www.cnbb.org.br/morre-bispo-emerito-da-prelazia-de-sao-felix-do-araguaia-mt-dom-pedrocasaldaliga. Acesso em: 10 de agosto de 2020.
} 
mas, sobretudo, pelo envolvimento com o guerrilheiro e ex-deputado Carlos Marighella.

Os casos selecionados foram aqueles que tiveram maior repercussão na imprensa, com maior número de matérias. A maioria dos textos noticiosos selecionados diz respeito a padres estrangeiros, porque, no arquivo, poucos fazem referência a padres brasileiros.

A base empírica desta análise fundamenta-se nas matérias de quatro jornais de grande circulação: Jornal do Brasil, O Globo, Folha de S.Paulo e $O$ Estado de S.Paulo, veiculadas entre 1968 e 1977. Esses jornais foram escolhidos por três motivos: serem de circulação nacional; terem sobrevivido ao regime militar; apresentarem presença no arquivo mais constante que os demais.

A partir de um processo de triagem com foco na repercussão dos casos e nesses quatro jornais, foi possível chegar ao total de 53 matérias, ficando a amostra assim constituída: 10 referem-se ao caso dos religiosos franceses; 15 ao dos religiosos dominicanos; 5 ao do padre Jentel; 15 ao do padre Romain Zufferey; 8 ao do bispo dom Pedro Casaldáliga. De todas as matérias, 13 são do Jornal do Brasil, 12 de O Globo; 16, de O Estado de S.Paulo; 12 da Folha de S.Paulo.

A análise das 53 matérias teve como base os valores-notícia elencados por Galtun e Ruge (1999, p. 71): frequência, amplitude, intensidade, equivocidade, significância, consonância, imprevisibilidade, continuidade, composição, referência a nações de elite, a pessoas de elite, a algo negativo. Dentre esses, foram observados aqueles que mais se aplicaram aos casos em estudo, sendo a imprevisibilidade, a personificação, a referência a nações de elite, a amplitude e a significância.

Embora a amostra seja relativamente pequena se comparada ao total de matérias do arquivo jornalístico da CNBB referentes às relações Igreja e 
Estado durante a ditadura militar ${ }^{8}$, ela evidencia um período crucial dessa relação: o momento em que a Igreja se viu atingida, por meio das acusações e repressões aos seus religiosos.

\section{CNBB como promotora de notícias}

Os cinco casos de religiosos acusados pelo regime militar de praticar atividades subversivas ganharam ampla visibilidade na imprensa brasileira. A atuação da CNBB como promotora de notícia foi bastante significativa se considerado o contexto no qual ocorreram os fatos. Os promotores de notícias, de acordo com Molotch e Lester (1999, p. 38), são aqueles que "identificam [...] uma ocorrência como especial, com base em algo, por alguma razão, para os outros". Eles têm a iniciativa de agendar a imprensa sobre assuntos de interesse público, por meio de estratégias de comunicação. Na época, a CNBB utilizou-se muito de releases, entrevistas e notas.

Nem sempre, porém, o agendamento foi suficiente para que as matérias fossem enquadradas a favor dos religiosos ou dos direitos humanos. Isto não significa que tenha sido em vão todo o esforço realizado pela Igreja católica. Pelo contrário, sua atuação foi de extrema importância para evitar que a imprensa divulgasse somente a versão oficial dos fatos. Houve outra questão relevante no processo de enquadramento dos acontecimentos: o contexto repressivo fundamentado na Lei de Segurança Nacional. Nos casos dos religiosos, assim como em outros acontecimentos da época divulgados pela imprensa, o enquadramento ocorreu de acordo com as circunstâncias a que estavam submetidos os jornalistas.

\footnotetext{
${ }^{8} \mathrm{O}$ arquivo jornalístico da CNBB compreende cerca de trezentas caixas, sendo que cada caixa comporta entre trezentas e quinhentas matérias, sobre os mais diversos gêneros jornalísticos e assuntos. Para a construção da amostra foram selecionadas oito caixas, das vinte que arquivam matérias sobre política, sobretudo, no que diz respeito à relação Igreja e Estado. O conteúdo das oito caixas analisadas refere-se ao período do regime militar no Brasil, de 1966 a 1979.
} 
A imprensa, durante a ditadura, tornou-se um espaço silenciado e manipulado pelos governos militares. Apesar de servir como meio de legitimação da força hegemônica, ela era má vista, por ser lugar de circulação de ideias, do contraditório. De acordo com a Lei de Segurança Nacional", "o Estado [...] vê com fraquezas os debates, as discussões e os questionamentos que caracterizam os regimes democráticos liberais" (COMBLIN, 1980, p.73). Para o regime, a imprensa era suscetível à infiltração das ideias comunistas. Ao lidar contra o pensamento crítico, os militares acreditavam estar destruindo o comunismo.

Qualquer oposição ao Estado, naquele momento, tornava-se suspeita de subversão. Para os militares, o país estava em guerra contra o comunismo internacional que, conforme expresso na Lei de Segurança Nacional, era o maior inimigo da nação. Não controlar os espaços de livre circulação de ideias poderia permitir a infiltração imediata do comunismo nos diversos segmentos sociais.

O Estado, tendo como referência a Lei de Segurança Nacional, implantou, no meio jornalístico, a cultura do medo e da obediência. Qualquer oposição a ele poderia resultar em repressão ao profissional da comunicação ou ao veículo para o qual trabalhava. Essa situação fez parte do cotidiano da imprensa durante a ditadura e passou a imagem de uma imprensa que consentiu com o status quo. Este consentimento, entretanto, não se deu por livre e espontânea vontade dos jornalistas, ou seja, não ocorreu porque os jornalistas acreditavam e aceitavam livremente o regime militar, mas por pressão psicológica e física.

9"A Segurança Nacional é a capacidade que o Estado dá à Nação para impor seus objetivos a todas as forças oponentes. Essa capacidade é, naturalmente, uma força. Trata-se portanto da força do Estado, capaz de derrotar todas as forças adversas e de fazer triunfar os objetivos nacionais" (COMBLIN, 1980, p. 54).

João Pessoa - Brasil | ANO 7 VOL.7 N.2 | JUL./DEZ. 2020 | p. 180 a 202 
A imprensa foi um dos espaços mais controlados pelo Estado. No governo da linha dura, por exemplo, o presidente Médici aumentou o controle sobre a imprensa, como parte da política de Segurança Nacional:

o Estado combatia a subversão com numerosas táticas: plantava notícias falsas; fazia pressão financeira sobre donos de veículos de comunicação que não se dispunham a cooperar; intimidava e prendia jornalistas; invadia, jogava bombas e praticava outras formas de violência tanto contra jornais do establishment quanto contra os de oposição" (SERBIN, 2001, p.348).

O controle imposto à imprensa, no entanto, não foi total, pois cada governo que assumiu o poder queria mostrar para a sociedade que o país seguia rumo à democracia. "Cada um dos quatro generais que sucederam na Presidência da República desde 1964 anunciou que sua tarefa consistia em preparar a volta à democracia, deixando mesmo crer que seria o último presidente militar" (COMBLIM, 1980, p.71).

Para assegurar essa imagem perante a sociedade, o regime evitou mostrar que havia censura. Agiu nos bastidores, de forma que poucas pessoas perceberam a situação na qual se encontrava a imprensa brasileira. De acordo com Kushnir (2004, p. 35), "a postura de vigiar e reprimir, nesse parâmetro, teve (e tem) a intenção de manter uma (imaginária) harmonia social".

Esse contexto interferiu no processo de construção das notícias. Os jornalistas enfrentaram muitas dificuldades que devem ser levadas em consideração ao se analisarem os enquadramentos dos fatos. São questões que implicaram na forma como os acontecimentos foram apresentados ao leitor.

Arrazoar a ação de proibir e censurar, de negar ao outro o direito de acesso a determinados temas; vigiar pessoas, ditar normas de conduta, excluir palavras do vocabulário; forjar de maneira brutal uma nova realidade, essas são algumas das indagações centrais e das preocupações acerca das estratégias do interdito (KUSHNIR, 2004, p. 36) 
No que diz respeito à Igreja católica, percebe-se, sobretudo pelos bilhetinhos ${ }^{10}$, os obstáculos que os jornalistas encontraram para noticiar fatos relacionados a esta instituição religiosa. A divulgação de nomes de bispos e de acontecimentos envolvendo religiosos foi censurada pelo regime. Ainda assim, um número significativo de casos envolvendo padres, freiras, bispos ganhou visibilidade na imprensa, pois foram acontecimentos que romperam com a normalidade e que apresentaram valores-notícia capazes de transformá-los em acontecimentos noticiosos.

\section{Casos de religiosos como valor-notícia}

De acordo com Wolf (2003, p. 152), a "hipótese da agenda setting sustenta que a mídia é eficaz na construção da imagem da realidade que o indivíduo começa a estruturar". Para construir essa imagem da realidade é necessário um processo, durante o qual o jornalista identifica, entre diversos acontecimentos, apenas os que podem se tornar notícias; os seleciona e os transforma em notícia.

Esse processo de construção da notícia não acontece de forma aleatória. As notícias possuem valores, conhecidos como valores-notícia (news values), que são um dos componentes da noticiabilidade, definida como "o conjunto de elementos por meio dos quais o aparato informativo controla e administra a quantidade e o tipo de acontecimento que servirão de base para a seleção das notícias" (WOLF, 2003, p. 202). Os valores-notícia são "critérios de relevância difundidos ao longo de todo o processo de produção" (WOLF, 2003, p. 202). Eles funcionam como linhas guias, como regras práticas que indicam o que deve ser enfatizado ou omitido.

A construção das notícias também compreende outros critérios de noticiabilidade. Para facilitar sua atividade diária, os jornalistas adotam procedimentos ante a pressão do tempo e de outros possíveis

\footnotetext{
10 Os bilhetinhos eram normas estritas impostas pelos governos militares e enviados aos meios de comunicação. Seu teor era voltado, sobretudo, aos assuntos proibidos de serem divulgados pela imprensa, entre eles, vários sobre a atuação da Igreja.
}

João Pessoa - Brasil | ANO 7 VOL.7 N.2 | JUL./DEZ. 2020 | p. 180 a 202 


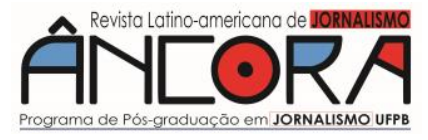

\section{Eliane LACERDA - Robson DIAS - Victor GOMES}

constrangimentos profissionais. Em síntese, os critérios de noticiabilidade requerem "uma noção do que é notícia, uma suposição do que o público espera ver noticiado e um reconhecimento das condições organizacionais de atender a essa demanda" (BENEDETI, 2006, p. 52). Os critérios de noticiabilidade são usados para a interpretação do real. Eles têm a capacidade de construir a realidade e reduzirem a complexidade, simplificando a imagem do mundo.

\section{Imprevisibilidade}

Com relação aos casos estudados, ressalta-se que, no Brasil, a prisão de religiosos foi e ainda é notícia . Trata-se de um assunto que rompe a normalidade. É o que Duarte (1999, p.28) chama de inversão ou imprevisibilidade.

A imprevisibilidade está associada ao que não se prevê, ao que não se espera que possa acontecer. Em um país de maioria católica e, especialmente, durante um regime que a Igreja ajudou a instalar, o inesperado estava não no fato de representantes da Igreja se envolverem com questões sociais ou políticas, mas no fato de serem eles presos, tachados de subversivos e até ameaçados de expulsão do País, como destacam, nos títulos e subtítulos, as notícias das figuras 1 e 2 :

Figura 1 - Termos prisão e subversão aparecem como título da matéria sobre os padres franceses

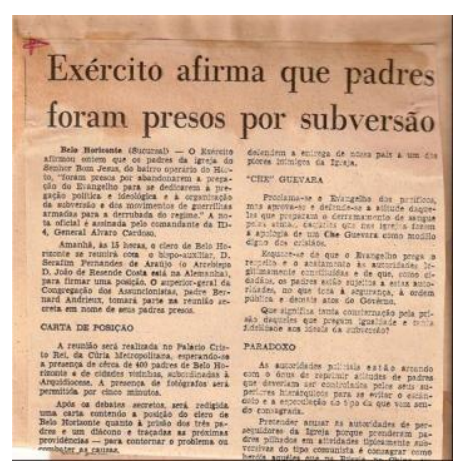

Fonte: Jornal do Brasil (03/12/68) 
Figura 2 - Notícia sobre possível expulsão de dom Pedro Casaldáliga

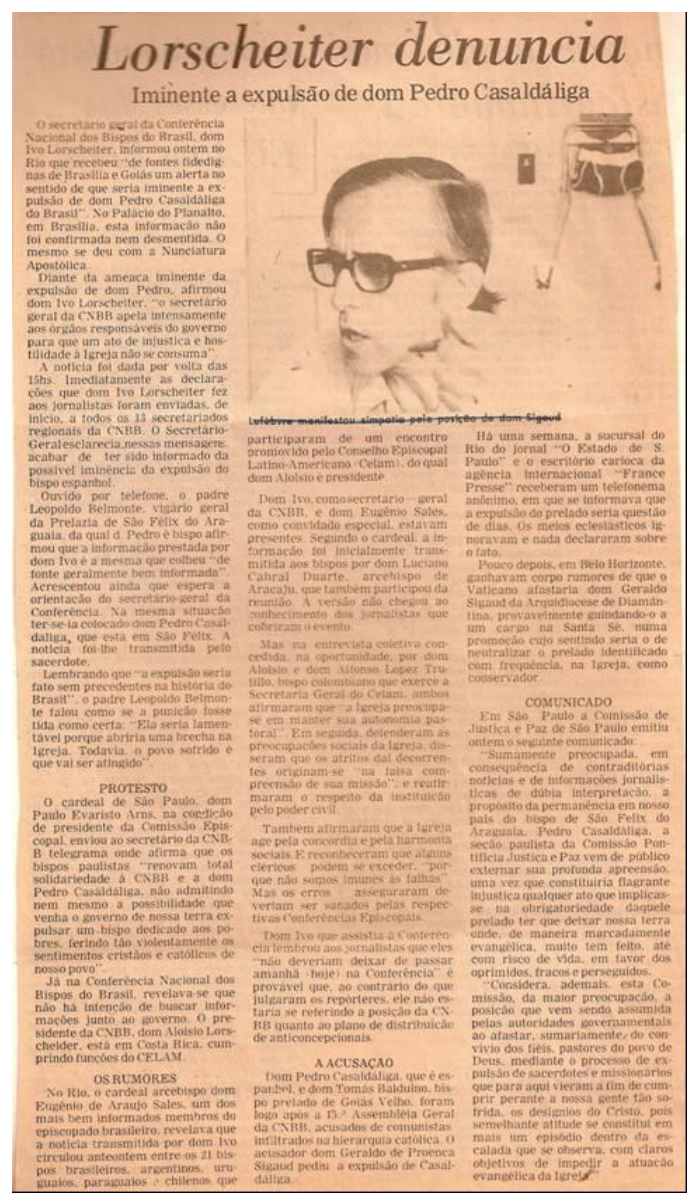

Fonte: Folha de S.Paulo (30/07/77)

O inesperado não era, portanto, o trabalho social ou político desenvolvido por padres ou freiras, pois a Igreja católica já atuava nessa linha desde a criação da esquerda católica, nas décadas de 1940 e 1950, o inesperado era a prisão de religiosos como criminosos, considerados uma ameaça ao Estado por suas práticas "subversivas". Por isso, o destaque nas notícias para palavras como: prisão, subversão e expulsão. Foi o que também ocorreu com as poucas notícias sobre o padre Jentel, como consta na Figura 3.

Figura 2 - Notícia sobre possível expulsão de dom Pedro Casaldáliga

João Pessoa - Brasil | ANO 7 VOL.7 N.2 | JUL./DEZ. 2020 | p. 180 a 202 Revista Latino-americana de Jornalismo | ISSN 2359-375X

Programa de Pós-Graduação em Jornalismo - UFPB 


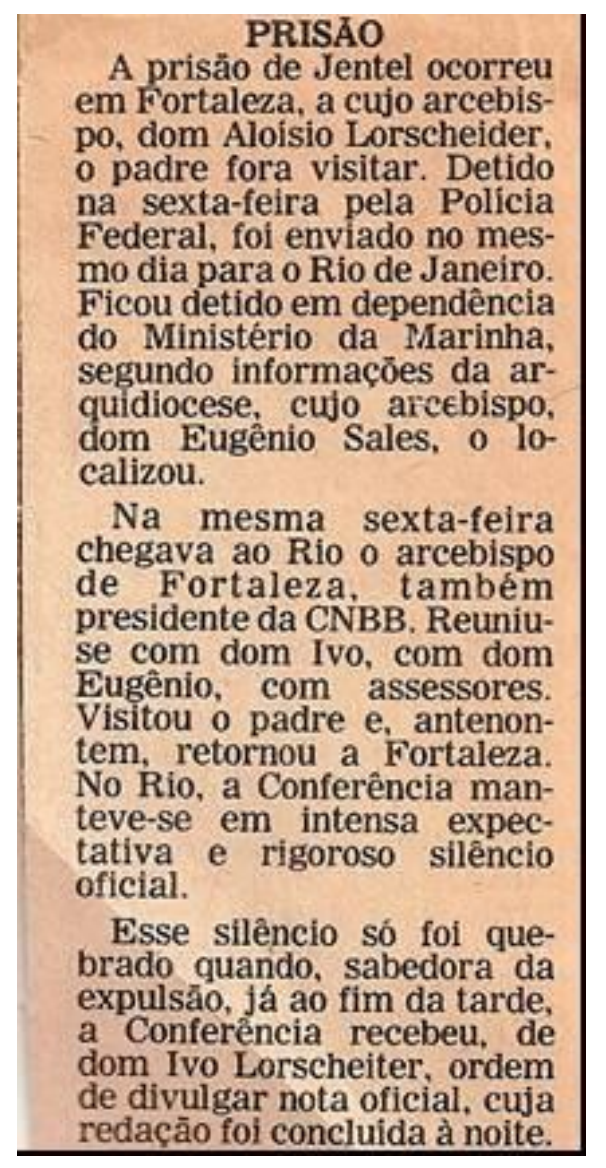

Fonte: Folha de S. Paulo (16/12/75)

Esse tipo de acontecimento era incomum, raro, porque a Igreja, de sua base à cúpula, desfrutava de credibilidade ante a sociedade. Embora muitas vezes fosse alvo de críticas, era uma instituição respeitada, não somente por sua tradição, mas também por muitas de suas ações. Para Duarte (1999, p. 29), o inesperado se opõe ao racional:

O racional é da ordem do previsível, da sucessão monótona das causas, regida por regularidades e por leis; o acontecimento é imprevisível, irrompe acidentalmente à superfície epidérmica dos corpos como reflexo inesperado, como efeito sem causa, como puro atributo. (Duarte, 1999, p.29)

O inesperado também adveio do rompimento das relações entre Igreja e Estado, pois esta outrora apoiara o golpe de 64 e depois se viu perseguida, numa situação delicada, com seus membros oprimidos pela ditadura. A Igreja deixou então a inércia e passou a ter uma atuação ativa contra o regime que 
ela havia ajudado a alcançar o poder. Esse rompimento foi um dos fatores que contribuíram para que os acontecimentos, aqui analisados, conquistassem o espaço público do jornalismo.

O secretário da Conferência Nacional dos Bispos do Brasil, dom Ivo Lorscheiter, informou ontem no Rio que 'recebeu de fontes fidedignas de Brasília e Goiás um alerta no sentido de que seria iminente a expulsão de dom Pedro Casaldáliga do Brasil. (...) Diante da ameaça iminente da expulsão de dom Pedro, afirmou dom Ivo Lorscheiter, "o secretário geral da CNBB apela intensamente aos órgãos responsáveis do governo para que um ato de injustiça e hostilidade à Igreja não se consuma" (FOLHA DE S. PAULO, 30/07/1977).

D. Aloísio disse que o caso do Padre Romain será examinado pela Comissão Justiça e Paz, que orientará a ação da CNBB. Acrescentou que tudo será feito para apoiar o sacerdote suíço e que espera que a Justiça funcione. "Normalmente, nesses casos, não aceitamos acordos diplomáticos. O Ministro da Justiça sabe disso. Não seria digno à condição de sacerdotes. Nós estamos sempre do lado da verdade", concluiu (JORNAL DO BRASIL, 22/07/77).

$\mathrm{Na}$ análise, pôde-se observar que a reação da Igreja e, consequentemente, a divulgação deste conflito com o Estado na imprensa, foi muito importante para uma solução menos trágica de alguns dos casos, evitando, inclusive, torturas e expulsões desses religiosos do País. Diferentemente do que aconteceu quando a Igreja silenciou a respeito de algumas perseguições, como a que ocorreu com os padres dominicanos, em 1969, quando onze religiosos foram presos e submetidos à tortura.

\section{Personificação}

Outro valor-notícia observado nos casos dos religiosos é a referência a pessoas ou personificação. De acordo com Galtung e Ruge (1999, p.68):

as notícias têm uma tendência para apresentar os acontecimentos como frases onde existe um sujeito, uma denominada pessoa ou coletividade composta por algumas pessoas, e o acontecimento é então visto como uma [consequência] das ações desta pessoa ou destas pessoas. (Galtung e Ruge, 1999, p. 68)

Foi justamente isto que ocorreu nas notícias analisadas, ou seja, os acontecimentos foram vistos a partir do resultado das ações dos religiosos, que representavam um determinado segmento da sociedade, a Igreja católica.

João Pessoa - Brasil | ANO 7 VOL.7 N.2 | JUL./DEZ. 2020 | p. 180 a 202 195

Revista Latino-americana de Jornalismo | ISSN 2359-375X

Programa de Pós-Graduação em Jornalismo - UFPB 


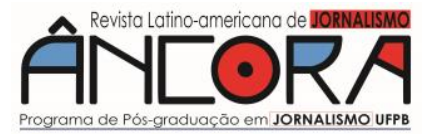

\section{Eliane LACERDA - Robson DIAS - Victor GOMES}

Dentre os casos mais emblemáticos desta análise, estão as notícias sobre a prisão dos padres dominicanos constantemente associados ao terrorismo, como mostra a Figura 4.

Figura 3 - Associação dos padres dominicanos ao terrorismo

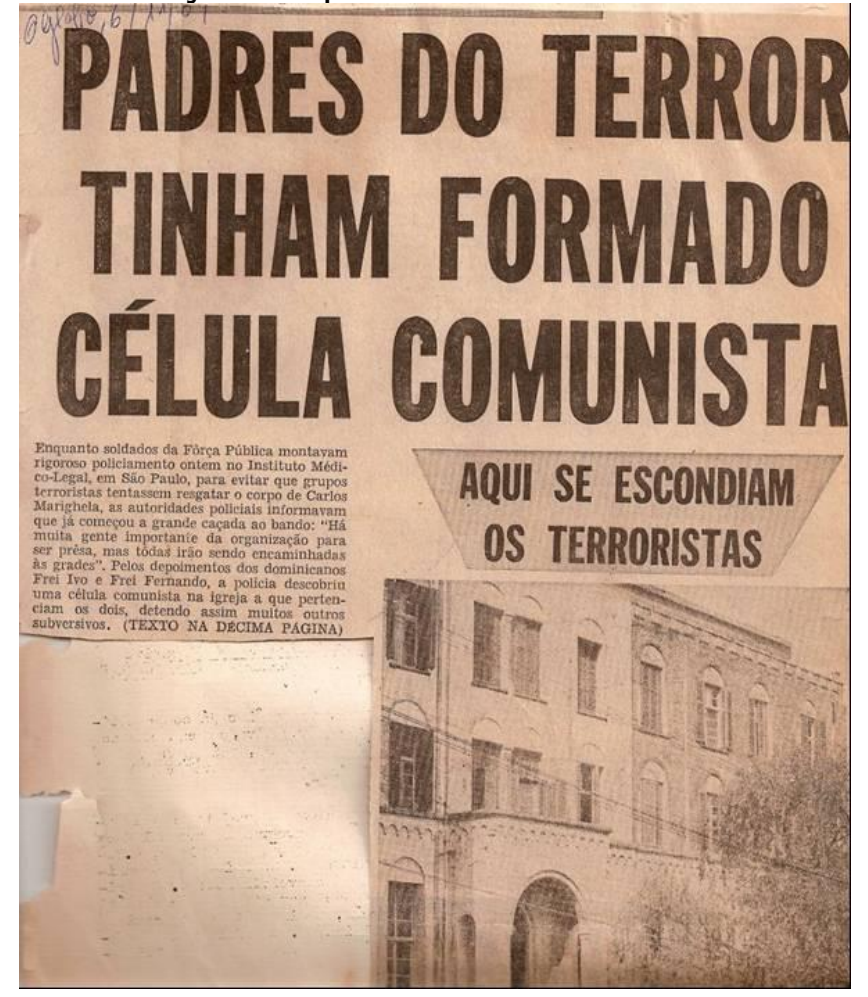

Fonte: $O$ Globo $(6 / 12 / 69)$

$O$ inesperado não esteve centralizado nas ações em si, mas no resultado que delas decorreu, como as prisões e as expulsões de religiosos. $O$ inesperado está relacionado "ao que não se imaginava", ou seja, não necessariamente ao fato de os religiosos estarem ligados de alguma maneira a questões sociais ou políticas, mas devido aos religiosos terem sido presos e ameaçados de expulsão ou mesmo expulsos do país. A personificação, por sua vez, refere-se aos religiosos, como representantes de um grupo social. $O$ caso dos Dominicanos exemplifica bem esta questão. Os onze religiosos presos foram pejorativamente tratados como "padres do terror". A matéria, sobretudo por 
meio do título, associa toda uma congregação religiosa ou segmento de religiosos ao terrorismo e ao comunismo.

\section{Nações de elite}

Outro valor-notícia presente é a referência a nações de elite, dado que dos cinco casos abordados, quatro dizem respeito a padres estrangeiros. 0 fato de se referir a nações de elite, aqui representadas por França, Espanha e Suíça, fez com que as notícias tivessem bastante repercussão. Os estrangeiros eram considerados grande ameaça ao regime militar, pois se tinha a ideia que os comunistas vinham de fora do país para influenciar as pessoas que aqui estavam. No caso dos religiosos, eram considerados comunistas disfarçados de padres. Apesar de terem ganhado bastante espaço na imprensa, os casos de religiosos estrangeiros, sobretudo aqueles que ocorreram nos últimos anos da ditadura, foram abordados de forma menos ofensiva do que os casos de brasileiros, pois os militares prezavam as relações diplomáticas entre as nações e queriam evitar a formação de uma imagem negativa do Brasil no exterior. A diferença de tratamento, inclusive, é perceptível no próprio título da notícia sobre o padre suíço Romain Zufferri, ameaçado de expulsão do Brasil em 1977, como consta na Figura 5.

Figura 4 - Matéria sobre possível expulsão do padre suíço do Brasil

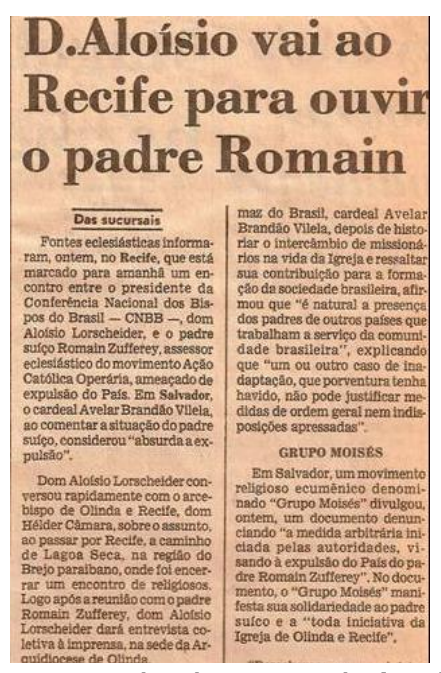

Fonte: O Estado de S. Paulo (20/07/77) 


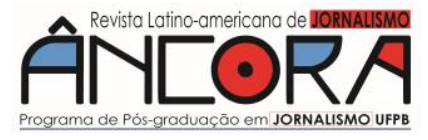

\section{Eliane LACERDA - Robson DIAS - Victor GOMES}

Nos casos envolvendo estrangeiros, as acusações foram menos agressivas, quase não há expressões metafóricas pejorativas nas notícias, procurava-se passar a imagem de que esses religiosos estavam sendo bem tratados nas prisões. Na figura 6, por exemplo, é possível observar uma notícia sobre a prisão dos padres franceses, afirmando que eles estavam "num apartamento de conforto".

Figura 6 - Notícia aborda o tratamento que padres franceses receberam na prisão

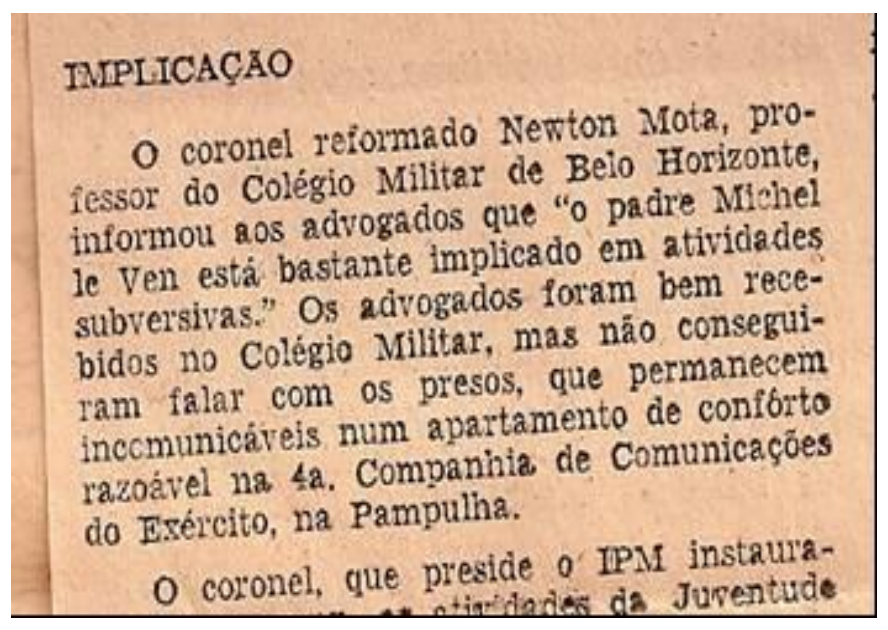

Fonte: Jornal do Brasil (03/12/68)

\section{Amplitude e significância}

Apesar do valor-notícia referente às nações de elite, as vidas dos religiosos acusados de praticar atividades subversivas tornaram-se um drama, sobretudo jornalístico. É o valor de amplitude. Ao defini-lo, Galtung e Ruge (1999, p. 64), citam o seguinte exemplo: "[...] quanto maior for a barragem, maior será a vontade de a sua inauguração ser relatada [...]; quanto mais violento for o assassínio, maiores serão os títulos". Os acontecimentos aqui abordados foram acontecimentos raros e graves, portanto, maior a necessidade de torná-los públicos. 
O valor-notícia da significância ou relevância está ligado a praticamente todos os outros valores. De acordo com Gans (1979 apud WOLF 2003, p. 214), ele corresponde aos seguintes requisitos:

a. história de pessoas comuns que passam a agir em situações insólitas, ou histórias de homens públicos, observados em sua vida privada cotidiana; b.histórias em que há uma inversão de papéis ("o homem que morde o cão"); c. histórias de interesse humano; $d$. histórias de feitos excepcionais e heróicos.

Os casos dos religiosos analisados neste artigo inserem-se nestes quatro quesitos. São histórias de homens "comuns", padres até então desconhecidos, com exceção de dom Pedro Casaldáliga, que se envolveram em situações insólitas, ou seja, contrárias ao costume, invertendo os papéis, pois para a sociedade eles deveriam estar em uma igreja e não em uma prisão. São histórias de interesse humano, por despertarem a curiosidade. Ao mesmo tempo, são histórias de feitos excepcionais e heróicos, pois, como a sociedade se encontrava dividida entre aqueles que apoiavam o regime e aqueles que eram contra, esses acontecimentos podiam despertar no leitor tanto a reação de apoio, de solidariedade, de orgulho como a reação oposta, de decepção, de revolta contra a atuação dos religiosos e da Igreja.

\section{Considerações finais}

Diante de um contexto histórico marcado pela censura, tornar um assunto visível por meio da imprensa foi um grande desafio. Entretanto, mesmo com todas as proibições da época, como aquelas que se davam por meio de bilhetinhos, alguns casos de religiosos perseguidos pelo regime militar apareceram nas páginas noticiosas por neles estarem intrínsecos alguns valores-notícia.

A imprevisibilidade, a personificação, a referência a nações de elite e amplitude foram, portanto, os principais valores-notícia encontrados nas 53 matérias analisadas sobre os religiosos acusados pela ditadura de praticar 


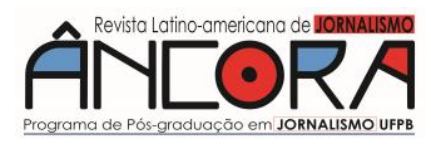

\section{Eliane LACERDA - Robson DIAS - Victor GOMES}

atividades subversivas. Esses valores contribuíram para que as prisões de religiosos, durante a ditadura, ganhassem visibilidade na imprensa.

A imprevisibilidade tornou pública a prisão de padres, ameaças e expulsões, dado que, sobretudo naquele momento, num país de maioria católica, não se esperava que religiosos fossem acusados e perseguidos por suas ações junto à sociedade, especialmente sendo presos, torturados e até mandado embora do Brasil, no caso específico do padre Jentel.

O valor-notícia da personificação causou sérios danos à imagem dos religiosos, porque eles representavam a Igreja católica ou no mínimo suas congregações. Nesse sentido, a Igreja foi chamada, por alguns jornais, de subversiva, comunista e até de terrorista.

Também teve muita relevância para os jornais os acontecimentos que envolveram religiosos estrangeiros. Aqui faz-se referência ao valor-notícia nações de elite. Embora, as notícias não façam menção a fatos ocorridos em nações estrangeiras, esses casos implicaram nas relações diplomáticas entre países. A entrada de padres estrangeiros no Brasil não era bem vista pelo regime. Ao mesmo tempo, os militares tinham grande preocupação em manter as relações diplomáticas e a boa imagem do Brasil no exterior.

A amplitude e significância fizeram com que estes casos tivessem bastante repercussão. Por isso, foram os escolhidos para esta análise, dentre todos os outros que constam no arquivo jornalístico da CNBB. Nesse sentido, a visibilidade a estes acontecimentos, por meio da imprensa, foi de suma importância, sobretudo para os padres. A exposição provocou ações e reações de diversas instituições, inclusive uma atuação mais forte da CNBB na defesa de seus religiosos. Muito embora, alguns desses episódios tenham resultado em tortura, como ocorreu com os dominicanos, e até na expulsão do padre Jentel do País.

\section{Referências}


BARROS, Raimundo Caramuru. A CNBB e o Estado brasileiro durante 0 interlúdio espartano (A Igreja e o Governo Militar de 1964 a 1985). In: Instituto Nacional de Pastoral (Org.). Presença Pública da Igreja no Brasil (1952-2002): Jubileu de Ouro da CNBB. São Paulo: Paulinas, 2003. 600p.

BENEDETI, Carina Andrade. A qualidade da informação jornalística: uma análise da cobertura da grande imprensa sobre os transgênicos em 2004. Dissertação (mestrado em Comunicação Social). Brasília: UnB, 2006. $167 p$.

BRUNEAU, Thomas. 0 Catolicismo Brasileiro em época de transição. São Paulo: Loyola, 1974. 442p.

COMBLIN, Pe. Joseph. A ideologia da segurança nacional: o poder militar na América Latina. Rio de Janeiro: Civilização Brasileira, 1980. 251p. DINES, Alberto; FERNANDES JR., Florestan; SALOMÃO, Nelma. Histórias do Poder: 100 anos de política no Brasil. 34.ed. São Paulo: Militares, Igreja e Sociedade Civil, 2000, 408p.

DUARTE, Adriano. O acontecimento. In: TRAQUINA, Nelson. Jornalismo: questões, teorias e 'estórias'. p.27-33. 2.ed. Lisboa: Vega, 1999.

FOLHA DE S. PAULO. Lorscheider denuncia. 30/07/1977.

FOLHA DE S. PAULO. Prisão. 03/12/75

GALTUNG, Johan; RUGE, Mari Holmboe. A estrutura do noticiário estrangeiro: a apresentação das crises do Congo, Cuba e Chipre em quatro jornais estrangeiros. In:

HALL, Stuart et al. A produção social das notícias: O mugging nos media. In: LEÃO XIII. Carta Encíclica Rerum novarum. São Paulo: Paulinas, 15 mai. 1891.

JORNAL DO BRASIL. Exercíto afirma que padres foram presos por subversão. $03 / 12 / 68$

JORNAL DO BRASIL. Implicação. 12/12/68

KUSHNIR, Beatriz. Cães de guarda: Jornalistas e Censores, do AI-5 à Constituição de 1988. São Paulo: Boitempo, 2004.

LACERDA, Eliane Muniz. 0 jornalismo nos limites da liberdade: um estudo da cobertura da imprensa sobre os casos dos religiosos acusados de praticar atividades subversivas durante o regime militar. 2007. $137 \mathrm{f}$. Dissertação (Mestrado em Comunicação)- Universidade de Brasília, Brasília, 2007.

MAINWARING, Scott. Igreja Católica e Política no Brasil (1916-1985).

Traduzido por: Heloísa Braz de Oliveira Prieto. São Paulo: Brasiliense, 1989. 300p.

MOLOTCH, Harvey; LESTER, Marilyn. As notícias como procedimento intencional: acerca do uso estratégico de acontecimentos de rotina, acidentes e escândalos. In:

O ESTADO DE S. PAULO. Dom Aloísio vai ao Recife para ouvir o padre Romain. 20/07/1977. 
O ESTADO DE S. PAULO. Igreja aguarda prova de culpa. 6/12/69. O ESTADO DE S. PAULO. Paris intercede pelos sacerdotes. 7/11/68. O GLOBO. Padre do terror tinham formado célula comunista. 06/12/69 SERBIN, Kenneth P. Diálogos na Sombra: Bispos e militares, tortura e justiça social na ditadura. Traduzido por: Carlos Eduardo Lins da Silva. São Paulo: Companhia das Letras, 2001. 566p.

SOARES, Ismar de Oliveira. Do Santo Ofício à Libertação: o discurso e a prática do Vaticano e da Igreja Católica no Brasil sobre a comunicação social. São Paulo: Paulinas, 1988, 400p. 